\title{
DETERMINATION OF LECTURER RECEPTION USING ANALYTICAL HIERARCHY PROCESS (AHP)
}

\author{
Hafizah Hanim ${ }^{1}$, Jefril Rahmadoni² \\ Universitas Andalas ${ }^{12}$ \\ hafizahhanim@it.unand.ac.id ${ }^{1}$, jefrilrahmadoni@it.unand.ac.id ${ }^{2}$
}

\begin{abstract}
During this time, the selection of non permanent lecturers, parts staffing difficulties in selecting lecturers. The obstacle faced is the large number of applicants who register to become prospective lecturers. So that the staffing or the campus must give extra time to choose prospective lecturers so that lecturers can be obtained that fit the desired criteria. The AHP (Analytical Hierarchy Process) method is a method in the decision-making process, this method performs a hierarchical structure calculation where the top level in the hierarchy is the goal to be achieved then the hierarchy below in the form of criteria in achieving goals and the lowest level is the alternatives in achieving goals.
\end{abstract}

Keywords : Analytical Hierarchy Process, Determination of Lecturer, Decision Support System.

\section{INTRODUCTION}

Decision Support System (Decision Support System) is a producer of information aimed at a particular problem that must be solved to support specific decision makers to solve problems. In order for the decision support to be fulfilled, a support method for the decision support system is used namely the Analytical Hierarchy Process (AHP) (Rais, 2016).

AHP is a method that involves many decision-making criteria. This method has been widely used in various fields such as politics, economics, IT, and especially in Information Systems. AHP method is considered suitable for determining the admission of permanent lecturers because it can consider many factors. This method also helps to assign weights to each factor with their respective effects. Because each factor has a different level of influence, AHP enables decision makers to formulate complex problems into simple forms of hierarchy, and to evaluate most qualitative and quantitative factors in a systematic form (Rakhman, Hidayanto, Hapsari, Sandhyaduhita, \& Budi, 2016).

Qualified teachers can produce quality students too. For this reason, the Decision Support System for Determining the Acceptance of permanent lecturers at IAIN Batusangkar using the AHP method can be used to assess the quality of prospective lecturers, with criteria determined by the campus management (Raharjo \& Darmadi, 2015).

Analytical Hierarchy Process (AHP) is proposed as a decision aid for solving unstructured problems, enabling decision making to formulate complex problems into simple forms of hierarchy and to evaluate a large number of qualitative and quantitative factors in a systematic form (Rakhman et al., 2016). AHP enables decision makers to formulate complex problems into simple forms of hierarchy and to evaluate a large number of qualitative and quantitative factors in a systematic. A university will find it difficult in managing large amounts of data when using very simple tools who is unable to produce information which is right and results in error in decision making (Akbar, Oktaviani, Tamimi, Shavira, \& Rahmadani, 2017). 


\section{LITERATURE REVIEW}

Decision Support System (DSS) or Decision Support System (DSS) is a system that is able to provide the ability to solve problems and the ability to communicate to problems with semi-structured and unstructured conditions. SPK aims to provide information, guide, predict and guide users in making good decision making (Raharjo \& Darmadi, 2015). DSS is more shown to support management in doing analytical work in situations that are less structured and with unclear criteria. DSS is not intended not to automate decision making, but rather provides an interactive tool that allows decision makers to carry out various analyzes using available models (Rais, 2016). Decision making is the result of the selection process of various alternative actions that can be selected with certain mechanisms, with the aim of providing the best results. The purpose of DSS is to help decision makers choose alternative decisions that process information obtained or provided using the decision making model (Khairina et al., 2016).

Decision Support System (DSS) as a system that has five components that can increase its usefulness(Sibagariang, R., \& Riandari, F., 2019):

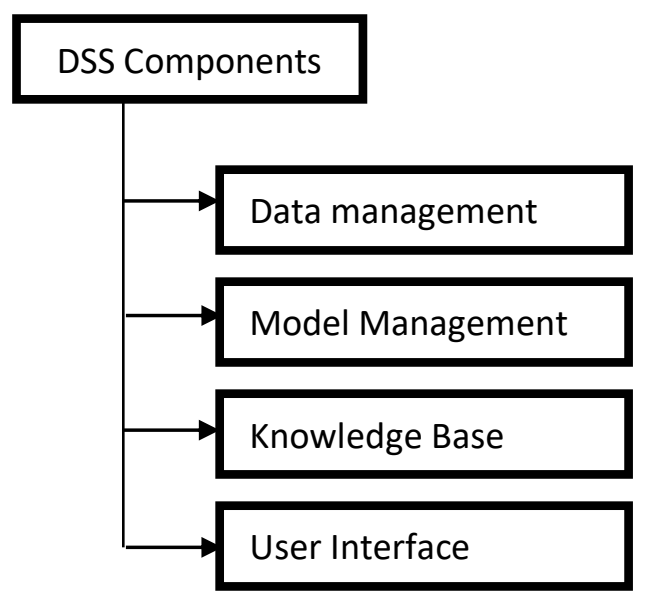

Fig. 1. Decision Support System Components

(1) Data management; Enter a database that contains data relevant to a situation and is managed by software called a database management system (DBMS). (2) Model Management; A software package that includes financial models, statistics, management science, or other quantitative models that provide analytical capabilities and appropriate software management. (3) Knowledge Base; Provide intelligence to increase the knowledge of decision makers. (4) User Interface; The user communicates and instructs the decision support system through this user interface.

The Analytic Hierarchy Process was developed by Dr. Thomas L. Saaty in the 1970s to organize information and expert opinion in choosing preferred alternatives. The working principle of AHP is the simplification of complex problems that are not structured, strategic and dynamic into parts and are listed in a hierarchy (Raharjo \& Darmadi, 2015).

Basically, the decision making process is to choose an alternative. The main tool of AHP is a functional hierarchy with the main input being human perception. The existence of a hierarchy allows a complex or unstructured problem to be divided into sub-problems, then organizes it into a hierarchy. AHP has many advantages in explaining the decision making process. One of them is graphically illustrated so that it is easily understood by all parties involved in decision making (Rais, 2016). AHP is a decision making method that involves many criteria that have been widely used in 
various fields. AHP is proposed as a decision aid to solve unstructured problems in politics and socio-economic knowledge management. AHP enables decision making for complex problems to be a simple form of hierarchy and for evaluating a large number of qualitative and quantitative factors in a systematic. AHP is designed to solve complex problems in the decision making process (Anis, Listiyono, \& Khristianto, 2015).

\section{RESEARCH METHODS}

State Islamic Institute Batusangkar as one Islamic university that is growing, requires the existence of a system that can help the leaders to determine each employee or faculty in the right areas of work with appropriate quality criteria. In this decision Support System research using methods Analytical Hierarchy Process ( AHP). The research activities requires a methodology that provides the framework. The framework is an overview of the steps that will be implemented so that research can be runs in a systematic and objective expected to achieve.

The framework of this study can be seen in Figure 1 below. These frameworks are steps to be taken in the settlement of issues to be discussed.

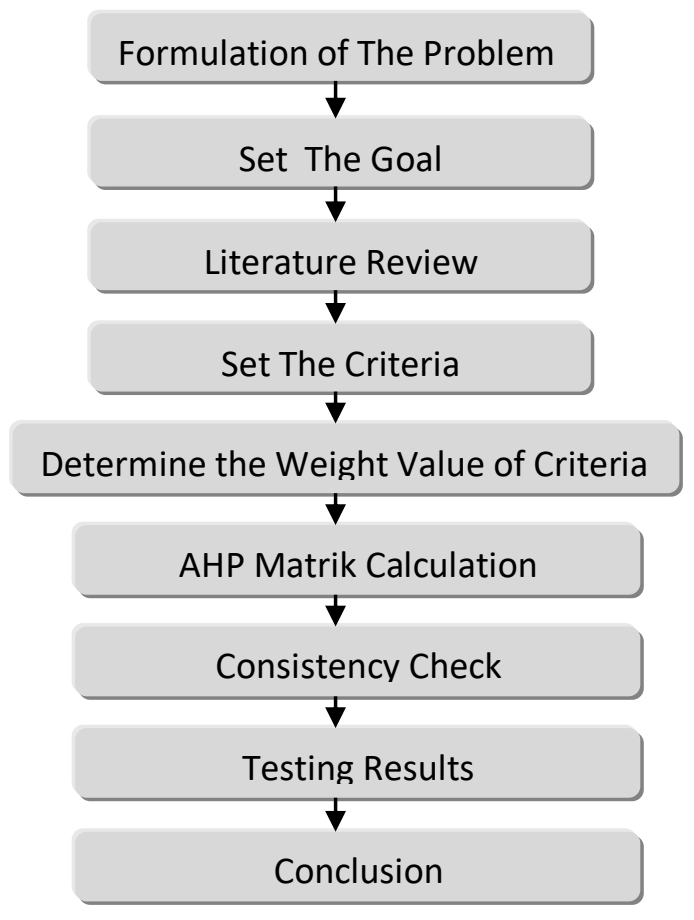

Fig. 2. Research Framework

\section{RESULTS AND DISCUSSIONS}

\section{a. Creating Hierarchy}

Based on the explanation of the data analysis system is obtained purpose or goal This decision support system, which is to get a permanent lecturer who berkualis and in accordance with the desired criteria institution. Alternatively namely lecturer candidates who applied. While the criteria in a hierarchical structure that is academic, competence, teaching certificate and physically and mentally healthy. The hierarchical structure used in this study can be seen in Figure 1.2 below. 


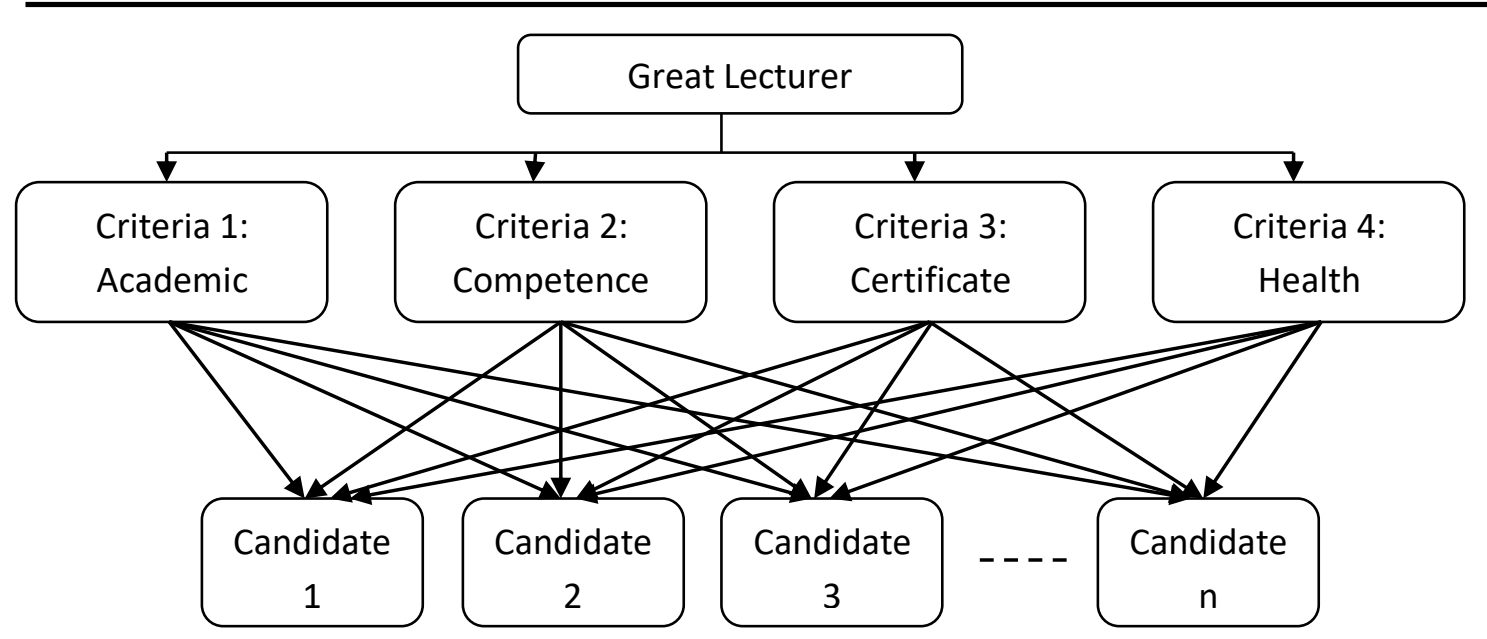

Fig. 3. Structure Hierarchy

\section{b. Calculate the AHP Comparison}

Calculate the comparison value with the calculation criteria matrix. So that later produce will be weight values or the priority value that will be used in the calculation of prospective lecturers. The priority value can in the Table 1

Table 1 - Table of Priority Criteria Value.

\begin{tabular}{lcccccc}
\hline & $\begin{array}{c}\text { Febria } \\
\text { Rahim }\end{array}$ & $\begin{array}{c}\text { Dissa } \\
\text { Oktarifah }\end{array}$ & $\begin{array}{c}\text { Mega } \\
\text { Rahmi }\end{array}$ & $\begin{array}{c}\text { Rossy } \\
\text { Endah P }\end{array}$ & $\begin{array}{c}\text { Sri } \\
\text { Madona }\end{array}$ & $\begin{array}{c}\text { Alternatif } \\
\text { Priority }\end{array}$ \\
\hline Febria Rahim & 0,556 & 0,714 & 0,455 & 0,455 & 0,455 & 0,175 \\
Dissa Oktarifah & 0,111 & 0,143 & 0,273 & 0,273 & 0,273 & 0,071 \\
Mega Rahmi & 0,111 & 0,048 & 0,091 & 0,091 & 0,091 & 0,029 \\
$\begin{array}{l}\text { Rossy Endah } \\
\text { Permata }\end{array}$ & 0,111 & 0,048 & 0,091 & 0,091 & 0,091 & 0,029 \\
Sri Madona & 0,111 & 0,048 & 0,091 & 0,091 & 0,091 & 0,029 \\
\hline
\end{tabular}

Table 2 - Table of Academic Criteria priority Value.

\begin{tabular}{lcccccc}
\hline \multicolumn{1}{c}{ Academic } & $\begin{array}{c}\text { Febria } \\
\text { Rahim }\end{array}$ & $\begin{array}{c}\text { Dissa } \\
\text { Oktarifah }\end{array}$ & $\begin{array}{c}\text { Mega } \\
\text { Rahmi }\end{array}$ & $\begin{array}{c}\text { Rossy } \\
\text { Endah P }\end{array}$ & $\begin{array}{c}\text { Sri } \\
\text { Madona }\end{array}$ & $\begin{array}{c}\text { Alternatif } \\
\text { Priority }\end{array}$ \\
\hline Febria Rahim & 0,556 & 0,714 & 0,455 & 0,445 & 0,455 & 0,175 \\
Dissa Oktarifah & 0,111 & 0,143 & 0,273 & 0,273 & 0,273 & 0,071 \\
Mega Rahmi & 0,111 & 0,048 & 0,091 & 0,091 & 0,091 & 0,029 \\
Rossy Endah & 0,111 & 0,048 & 0,091 & 0,091 & 0,091 & 0,029 \\
$\begin{array}{l}\text { Permata } \\
\text { Sri Madona }\end{array}$ & 0,111 & 0,048 & 0,091 & 0,091 & 0,091 & 0,029 \\
\hline
\end{tabular}

Table 3 - Table of Competence Criteria Value.

\begin{tabular}{lcccccc}
\hline \multicolumn{1}{c}{ Competence } & $\begin{array}{c}\text { Febria } \\
\text { Rahim }\end{array}$ & $\begin{array}{c}\text { Dissa } \\
\text { Oktarifah }\end{array}$ & $\begin{array}{c}\text { Mega } \\
\text { Rahmi }\end{array}$ & $\begin{array}{c}\text { Rossy } \\
\text { Endah P }\end{array}$ & $\begin{array}{c}\text { Sri } \\
\text { Madona }\end{array}$ & $\begin{array}{c}\text { Alternatif } \\
\text { Priority }\end{array}$ \\
\hline Febria Rahim & 0,238 & 0,238 & 0,238 & 0,238 & 0,238 & 0,079 \\
Dissa Oktarifah & 0,238 & 0,238 & 0,238 & 0,238 & 0,238 & 0,079 \\
Mega Rahmi & 0,238 & 0,238 & 0,238 & 0,238 & 0,238 & 0,079 \\
Rossy Endah & 0,238 & 0,238 & 0,238 & 0,238 & 0,238 & 0,079 \\
$\begin{array}{l}\text { Permata } \\
\text { Sri Madona }\end{array}$ & 0,048 & 0,048 & 0,048 & 0,048 & 0,048 & 0,016 \\
\hline
\end{tabular}

Table 4 - Table of Certificate Criteria Value.

\begin{tabular}{ccccccc}
\hline Certificate & $\begin{array}{c}\text { Febria } \\
\text { Rahim }\end{array}$ & $\begin{array}{c}\text { Dissa } \\
\text { Oktarifah }\end{array}$ & $\begin{array}{c}\text { Mega } \\
\text { Rahmi }\end{array}$ & $\begin{array}{c}\text { Rossy } \\
\text { Endah P }\end{array}$ & $\begin{array}{c}\text { Sri } \\
\text { Madona }\end{array}$ & $\begin{array}{c}\text { Alternatif } \\
\text { Priority }\end{array}$ \\
\hline Febria Rahim & 0,385 & 0,600 & 0,185 & 0,385 & 0,385 & 0,068
\end{tabular}




\begin{tabular}{lcccccc} 
Dissa Oktarifah & 0,077 & 0,120 & 0,556 & 0,077 & 0,077 & 0,032 \\
Mega Rahmi & 0,385 & 0,040 & 0,185 & 0,385 & 0,385 & 0,048 \\
$\begin{array}{l}\text { Rossy Endah } \\
\begin{array}{l}\text { Permata } \\
\text { Sri Madona }\end{array}\end{array}$ & 0,077 & 0,120 & 0,037 & 0,077 & 0,077 & 0,014 \\
\hline
\end{tabular}

Table 5 - Table of Health Criteria Value.

\begin{tabular}{lcccccc}
\hline \multicolumn{1}{c}{ Health } & $\begin{array}{c}\text { Febria } \\
\text { Rahim }\end{array}$ & $\begin{array}{c}\text { Dissa } \\
\text { Oktarifah }\end{array}$ & $\begin{array}{c}\text { Mega } \\
\text { Rahmi }\end{array}$ & $\begin{array}{c}\text { Rossy } \\
\text { Endah P }\end{array}$ & $\begin{array}{c}\text { Sri } \\
\text { Madona }\end{array}$ & $\begin{array}{c}\text { Alternatif } \\
\text { Priority }\end{array}$ \\
\hline Febria Rahim & 0,200 & 0,200 & 0,200 & 0,200 & 0,200 & 0,032 \\
Dissa Oktarifah & 0,200 & 0,200 & 0,200 & 0,200 & 0,200 & 0,032 \\
Mega Rahmi & 0,200 & 0,200 & 0,200 & 0,200 & 0,200 & 0,032 \\
$\begin{array}{l}\text { Rossy Endah } \\
\text { Permata }\end{array}$ & 0,200 & 0,200 & 0,200 & 0,200 & 0,200 & 0,032 \\
Sri Madona & 0,200 & 0,200 & 0,200 & 0,200 & 0,200 & 0,032 \\
\hline
\end{tabular}

Table 6-Table of Results.

\begin{tabular}{lcccccc}
\hline & & $\begin{array}{c}\text { Febria } \\
\text { Rahim }\end{array}$ & $\begin{array}{c}\text { Dissa } \\
\text { Oktarifah }\end{array}$ & $\begin{array}{c}\text { Mega } \\
\text { Rahmi }\end{array}$ & $\begin{array}{c}\text { Rossy } \\
\text { Endah P }\end{array}$ & $\begin{array}{c}\text { Sri } \\
\text { Madona }\end{array}$ \\
\hline 0,221 & Academic & 0,175 & 0,071 & 0,029 & 0,029 & 0,029 \\
0,449 & Competence & 0,079 & 0,079 & 0,079 & 0,079 & 0,016 \\
0,176 & Certificate & 0,068 & 0,032 & 0,048 & 0,014 & 0,014 \\
0,147 & Health & 0,032 & 0,032 & 0,032 & 0,032 & 0,032 \\
\hline
\end{tabular}

\begin{tabular}{ccc}
\multicolumn{3}{c}{ Table 7 - Table of Results. } \\
\hline No & Alternatif & $\begin{array}{c}\text { Final } \\
\text { Weight }\end{array}$ \\
\hline 1 & Febri Rahim & 0,331 \\
2 & Dissa Oktarifa & 0,271 \\
3 & Mega Rahmi & 0,199 \\
4 & Rossy Endah & 0,169 \\
& Permata & \\
5 & Sri Madona Saleh & 0,084 \\
\hline
\end{tabular}

Based on the calculation of the values in the table 6 shows that an alternative thread. Who have the greatest value is Febri Rahim.

\section{CONCLUSION}

Based on the results of this research, several conclusions can be made, including: (1) The use of the method Analytical Hierarchy Process (AHP)in this study can provide recommendations in making decisions for the determination of acceptance of Non-PNS permanent lecturers at the State Islamic Institute Batusangkar. (2) The institute can be facilitated in making decisions to determine candidates which lecturer the most appropriate and in accordance with the required criteria. (3) Expert Choice can be used to implement a support system decision using the method Analytical Hierarchy Process (AHP).

\section{References}

Akbar, R., Oktaviani, R., Tamimi, S., Shavira, S., \& Rahmadani, T. W. (2017). IMPLEMENTASI BUSINESS INTELLIGENCE UNTUK MENENTUKAN TINGKAT KEPOPULERAN JURUSAN PADA UNIVERSITAS. Jurnal Ilmiah Informatika, 2(2), 135-138. 
Anis, Y., Listiyono, H., \& Khristianto, T. (2015). ANALYTIC HIERARCHY PROCESS ( AHP ) SEBAGAI ALAT UNTUK PENGAMBILAN KEPUTUSAN ( SPK ) SELEKSI PEMASOK OBAT-OBATAN. 7(2).

Khairina, D. M., Asrian, M. R., Hatta, H. R., Komputer, I., Ilmu, F., \& Informasi, T. (2016). Sistem Pendukung Keputusan Untuk New Rekrutmen Karyawan Menggunakan tertimbang Metode Produk. 19-21.

Raharjo, J. D., \& Darmadi, A. (2015). Sistem Penunjang Keputusan Penerimaan Dosen dengan Metode Analytic Hierarchy Process. 5(1).

Rais, M. S. (2016). Sistem Pendukung Keputusan Untuk Pemilihan Lokasi Perumahan Menggunakan Analytical Hierarchy Process ( AHP ). 2(2), 59-72.

Rakhman, R. D., Hidayanto, A. N., Hapsari, I. C., Sandhyaduhita, P. I., \& Budi, I. (2016). Menerapkan Analytic Hierarchy Process untuk Mengukur Manajemen Pengetahuan Kesiapan di Lembaga Pemerintah. ICITSI.

Sibagariang, R., \& Riandari, F. (2019). Decision Support System for Determining the Best Wood For the Production Cabinet Using Bayes Method. Jurnal Mantik, 3(3, Nov), 99-103. 